\title{
Past, Present and Future of Mediation in Nordic Countries
}

\author{
Kaijus Ervasti
}

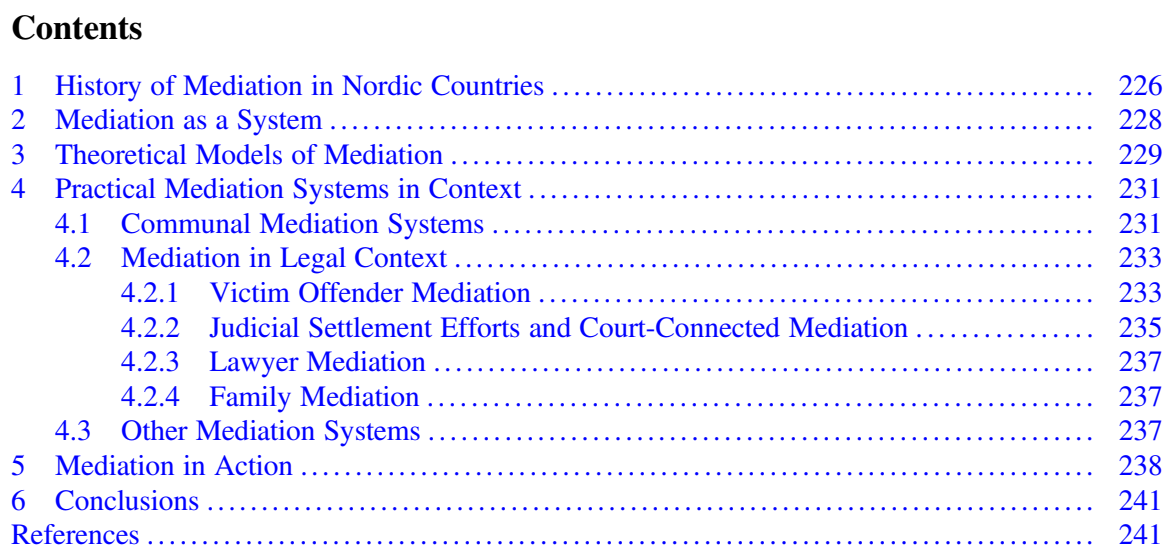

\begin{abstract}
In this article, I argue that it is useful to make a distinction between theoretical models of mediation, practical systems of mediation in context, and mediation in action. Using this distinction makes it possible to examine the relationship of the model of mediation, the context in which mediation is practiced and mediator behaviour, and to analyse the field of mediation and obtain a better understanding of mediation, as such, as a result. First, I offer a brief historical overview of how mediation has developed in the Nordic countries on a theoretical, institutional and practical level. Then, I unfold and examine which theoretical models are at play, what the different areas of practice are and how mediators interpret and implement theoretical models in their practice. One main problem is that mediators in their everyday work sometimes act in a different way than they think themselves or what theory of mediation postulates. In conclusion, I point to the
\end{abstract}

\footnotetext{
K. Ervasti $(\bowtie)$

Faculty of Social Sciences, University of Helsinki, Helsinki, Finland

e-mail: kaijus.ervasti@helsinki.fi
} 
need for further empirical and theoretical studies, as well as the development of mediation training in Nordic countries.

\section{History of Mediation in Nordic Countries}

In the last 50 years, there has been a significant number of writings on conflict resolution and mediation. There are a wide range of theoretical constructions, concepts and models dealing with these topics. In practice, there is also a huge number of new conflict resolution systems in Western countries. More and more conflicts will be resolved in an out-of-court system. Particularly mediation is today a widely used method to resolve conflicts in Western countries, including the Nordic countries.

In this article, I will introduce mediation systems in Nordic countries. At first there are some historical remarks on the development of mediation in Nordic countries. After that I will handle mediation as a system that has three elements: theoretical models of mediation, practical systems of mediation in context, and mediation in action. Finally, I will handle separately each of these elements.

Mediation has old roots in Nordic countries. Modern law, a trained legal profession and jurisprudence are phenomenon of the late eighteenth and nineteenth centuries in Nordic countries. In pre-modern time, legal, administrative issues and common things of the people were handled in a local assembly called ting. Criminal cases, civil cases, disputes concerning ownership of land and the like were all handled in ting. A large part of the local people took part in the decision making process. Decision making was based on consensual negotiation of local people. For example, resolution in homicide cases often entailed compensation to the family of the victim. It is not difficult to see similarities between pre-modern conflict resolution systems and late modern or post-modern conflict resolution system and mediation systems in Nordic countries (Letto-Vanamo and Tamm 2017).

The late eighteenth and nineteenth century saw the appointment of special conciliation boards in Denmark, Norway and Iceland, but not in Finland or Sweden. According to the regulation of 1795 in Denmark and Norway, all civil case, in general, should be subject to settlement efforts prior to going to court. These conciliation boards handled mostly civil cases, but also cases of defamation, debt, marriage and violence. This system has been abolished in Denmark and Iceland, but it is working still in Norway (Vindeløv 2012; Nylund 2014). Norwegian boards try to get settlement in civil cases but gives also judgments. Members of boards are laymen. The conciliation boards handle about 80,000 cases per year. ${ }^{1}$ Nordic conflict

\footnotetext{
${ }^{1}$ See http://www.forliksraadet.no/index.php?page_id=2032.
} 
resolution systems have had also an impact on the US system of the turn of the century 1900. In Galanter's (1986) words:

Before the turn of the century, conciliation model after the conciliation courts of Norway and Denmark had been urged on American as a superior way of dealing with disputes. Although its proponents emphasized conciliation tribunals as informal forums for producing mutual accord, separate from the ordinary courts, the conciliation idea became linked with the notion of providing accessible and inexpensive justice to small claimants in the courts.

It has been also said that Nordic court procedure, especially in Finland and Sweden, has been almost until into modern time "peasant". For example, in Finland, there was a board of lay judges both in civil and criminal cases in the countryside at the end of the 1900s. Today, lay judges are used only in some criminal cases. Court proceedings are also less formal in Nordic countries, as in many other countries. In Finland and Sweden, judges or lawyers do not have any specific clothing like a cloak and wig. It is also not mandatory to use a lawyer in court cases in Finland. It has been also said that Nordic conflict resolution culture and court culture has been very pragmatic in promoting settlement and avoiding full-scale trial.

In the early 1980s the modern mediation movement has risen in Nordic countries, especially in Norway and Finland. Both countries introduced new victim offender mediation systems. The background of this movement was the thinking of Norwegian sociologist Nils Christie (Nylund 2014). Nordic welfare states include several institutions that, among other tasks, aim to resolve conflicts such as different kind of advisory services, boards, ombudsmen, and self-regulatory systems. Mediation systems exists in both the public and private sectors.

Conflict resolution systems are always culturally specific and chosen (MenkelMeadow 1996). In the last 20 years alternative conflict resolution systems in Nordic countries have become more common. Mediation has increased strongly in the Nordic countries especially in the 2000s. New mediation systems have developed and also the caseload in mediation has increased (see e.g. Nylund 2010; Vindeløv 2012; Adrian and Mykland 2014; Ervasti and Nylund 2014; Ervasti and Salminen 2017). Finland, Norway and Denmark, for example, have introduced new court connected systems (see Bernt 2011; Mykland 2011; Adrian 2012; Ervasti 2014; Ervasti and Nylund 2014; Ervo and Nylund 2014).There is also a lot of interaction amongst researchers in these countries. Sweden and Iceland has not been as active in this area. There are not such court-connected mediation systems in Sweden and Iceland as exists in other Nordic countries. ${ }^{2}$

\footnotetext{
${ }^{2}$ Social democrats have been for a long time Sweden's largest political party. The party has been against privatisation of infrastructure. According Lindel (2004): "private ADR would probably be seen as a risk to the welfare system" in Sweden. That can be one reason why Sweden do not pass the same pace with other Nordic countries.
} 


\section{Mediation as a System}

Mediation is one of the basic conflict resolution systems. ${ }^{3}$ There are several definitions of mediation. There is also a wide range of views on mediation. ${ }^{4}$ Discussion has spoken of ideologies, policies, processes, institutions, models, practices and applications of mediation. Often are made a distinction between theoretical models of mediation and mediation in practice. That distinction has used in the names of many books and articles (e.g. Folberg and Milne 1988; Alfini et al. 2001; McCorkle and Reese 2005; Adrian 2012). Sometimes this categorisation refers to the distinction between theoretical questions of mediation and more practical issues-such as mediation techniques. Sometimes it has used as an analytical tool in empirical studies to make a distinction between theoretical models of mediation and mediation in reality.

It is useful to make a distinction between theoretical models of mediation, practical systems of mediation in context, and mediation in action. ${ }^{5}$ Using three categories makes it possible to get more analytical power to view mediation as a system. Sometimes it is difficult to follow the discussion of mediation because writers are not always telling the context of their approach. Discussion is more rational if the theoretical and practical as well as action level context are clear.

All these dimensions of mediation are in interaction with each other. Theoretical models of mediation have an influence to practical mediation systems and to mediation in action. Also practical mediation systems effects to theoretical models and mediation in action. Mediation in action has own influence also to theoretical models and practical systems.

This model is heuristic. It is useful for comparing how different elements (theoretical models, practical systems, mediation in action) are interacting each other, e.g. how theoretical models are influencing — or not—-to the practical mediation systems and mediation in action. It can be also useful in comparing different mediation systems and mediation in different countries and cultures. It can be used as a tool in critical research by disclosing what kind of gaps and lacks there is between theoretical models, practical systems and mediation in action (Fig. 1).

There is many kind of theoretical models of mediation. In this time there is many kind of theoretical discussion concerning mediation in Nordic countries like theoretical models of mediation and taxonomy of them (Ervasti and Nylund 2014), Vindeløvs "reflexive mediation" (Vindeløv 2012), creativity of mediation agreements (Adrian and Mykland 2014), mediation in the light of understanding of identity (Asmussen 2018) and meaning of restorative approach in mediation (Rasmussen 2018).

\footnotetext{
${ }^{3}$ According Goldberg et al. (1999), there is three primary processes of conflict resolution: negotiation, mediation and adjudication. They have called variants of arbitration, mini-trial, summary jury trial and ombudsman as a hybrid processes. Ervasti and Nylund (2014), have seen also evaluation as a primary process of conflict resolution.

${ }^{4}$ In Nordic countries mediation is often defined very broadly and there is not different words for "mediation" and "conciliation". See Nylund 2018.

${ }^{5}$ Originally this categorising has been made by Ervasti and Nylund (2014), but they have the categories of theoretical models of mediation, applications of mediation, and mediation in action.
} 
Fig. 1 Mediation as a system

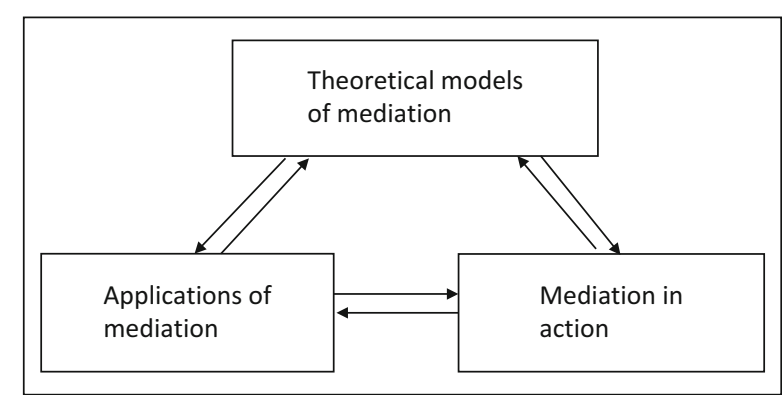

There is also a great variety of different applications, ${ }^{6}$ programmes or practical systems of mediation in context. In Nordic countries there exists community mediation, school mediation, neighbourhood mediation, multicultural mediation, courtconnected mediation, workplace mediation, commercial mediation and international peace mediation. In the European Union there has been discussion of the possibilities of alternative dispute resolution (ADR) and mediation in administrative law (Dragos and Neamtu 2014). In Nordic countries there is not yet institutionalised mediation systems in the field of administrative law.

The third level is mediation in action. There are thousands of mediators in all Nordic countries who are working as professional mediators or as laymen in different kinds of practical mediation systems. They have many kind of theoretical and practical training in different systems. Moreover, there is a great variety in their activities and behaviour. One very interesting research topic is how is the relationship between theoretical model, practical system and mediation in action in different contexts.

\section{Theoretical Models of Mediation}

Often mediation has been understood as an assisted negotiation or facilitation of negotiation. The "purest" form of mediation is facilitative mediation where a mediator helps the parties to find their own solution. The facilitative model of mediation is the most common model of mediation in civil cases also in Nordic countries like in other Western countries. ${ }^{7}$

\footnotetext{
${ }^{6}$ E.g. Menkel-Meadow (2016), Umbreit (1988), Folberg and Milne (1988) have used the term "applications".

${ }^{7}$ Discussion of the theoretical models of mediation (in civil cases) has been dominated by division of mediation into a facilitativeand evaluative model made by Leonard Riskin (1996) 20 years ago. Since then transformative mediationhas become the third primary model of mediation in civil cases. For a discussion of mediation models, see Menkel-Meadow (1984), Bush and Folger (2005), Winslade and Monk (2001).
} 
Mediation and conflict resolution in Nordic countries have been greatly influenced by theories prevalent in the United States at this time. However, there is also old indigenous mediation systems in Nordic countries as well as theoretical models of conflict resolution and mediation. In Nordic countries conflict resolution research has been strongly linked to sociology of law or socio-legal studies. Especially in the Norway, there has been many well-known theoretical researchers in this area. ${ }^{8}$

Norwegian professor Wilhelm Aubert (1922-1988) has developed conflict theory in Nordic countries in the 1960s and 1970s. He made a distinction of two types of conflict and conflict resolution: competition and dissensus (Aubert 1963; Aubert 1967) Another Norwegian professor, Torstein Eckhoff (1916-1993) has also had significant influence on Nordic conflict resolution research. He has analysed the roles of judges, mediators and administrators in conflict resolution. In his quite well known article from the 1960s Eckhoff handles key concepts of conflict resolution such as "conflict", "dispute", "solution", "outcome", "opinions" and "interests". He makes also a distinction between three types of conflict resolution methods: "to mediate", "to judge" and "to administer". According Eckhoff: "the third party's interest in the outcome and the power-relationship between him and the parties are important factors which will be considered". There can be various reasons for the participation of a third party in the conflict resolution. In mediation the parties try to get an agreement by appealing to their own interests. The activity of a judge is related more to the level of norms rather than the level of interests. The administrator decides how three conflict should be resolved-like also the judge. According Eckhoff, in contrast, the judge "who merely pretends to determine what already is right, the administrator establishes an arrangement which is character of being new"-in other words, what the rights and duties should be in the future (Eckhoff 1966).

A third Norwegian professor, Johan Galtung (1930-), is known as the principal founder of the discipline of peace and conflict studies (see e.g. Galtung 2000). A fourth Norwegian professor, Thomas Mathiesen (1933-), is best known as a criminologist, but has also some studies in conflict resolution. According to Mathiesen, conflict of interests and use of power will transform to conflict of norms when the conflict is indispensable in public forum. Courts and university lawyers develop conversion of conflict of interests to conflict of norms (Mathiesen 1979).

Especially a fifth Norwegian professor, Nils Christie (1928-2015), has had a great significance in building victim offender mediation systems in different Nordic countries in the 1980s and early 1990s. It is his influence that the mediators in victim offender mediation (VOM) are laymen in Nordic countries. In many other countries, mediators are professionals and work in probation service, for instance. He has had great influence also in many other mediation systems such as community mediation, school mediation and workplace mediation in Nordic countries.

Christies' article Conflict as Property (1977) has inspired many researchers, practitioners and system designers in Nordic countries and also in other Western countries

\footnotetext{
${ }^{8}$ For trends in sociology of law in Scandinavia see Hammerslev (2010), and Hammerslev and Madsen (2014).
} 
(Albrecht 2010). The thinking of Christie lies in the idea of communities, where people should handle their own problems and conflicts so that they can growth as a humans. He has seen conflicts as a potential for activity and participation. According to Christie, lawyers in reality steal conflicts of people in Western countries. According to Christie, courts in criminal cases are victim-oriented organisations where the victim has been left behind. He has been an advocate of lay-oriented court system.

In this time, the common theoretical approach in victim offender mediation in Nordic countries is restorative justice. It means that the theoretical basis of VOM has changed. The thinking of Christie has influenced restorative justice theory (Braithwaite 1996). But there are also some differences.

Nowadays a facilitative mediation model combined with an interest-based approach is the common model of mediation in civil cases in Nordic countries like also in other Western countries (Vindeøv 2007, 2012). Denmark has generated "reflexive" mediation, which is a (non)model of sorts, as a new perspective on conflict resolution and mediation. The model has great importance in Denmark today. The key to reflexive mediation lies in the values and understandings of conscious mediation practice. Reflexive mediation is eclectic and allows inspiration to be drawn from different mediation models. However, the process is not anything goes. The basic values of mediation must be respected to call the process mediation.

\section{Practical Mediation Systems in Context}

There are many kind of practical mediation systems in Nordic countries (Ervasti and Nylund 2014). There are some differences but also some similarities between different countries. Figure 2 describes practical mediation systems in Nordic countries.

\subsection{Communal Mediation Systems}

Many new mediation systems were introduced in the Nordic countries in 1980s, 1990s, and 2000s. Those systems, such as victim offender mediation and courtconnected mediation, have risen in legal context. It is very interesting that there has not been much private mediation systems out of the legal context before the 2000s.

In these days, there is in Finland, like also in other Nordic countries, communal mediation systems. In early 2000s there was some experiments of mediation in multicultural conflicts in Finland. In 2014, the Finnish refugee Council founded the Centre for Community mediation. That system has handled many kinds of conflicts in neighbourhoods and local communities. The background of that system is community mediation model from the United States. But also the thinking of Christie and restorative justice model are included. In Finland, there is about 100-200 cases per year in community mediation. In Norway, the National Mediation Office provides 

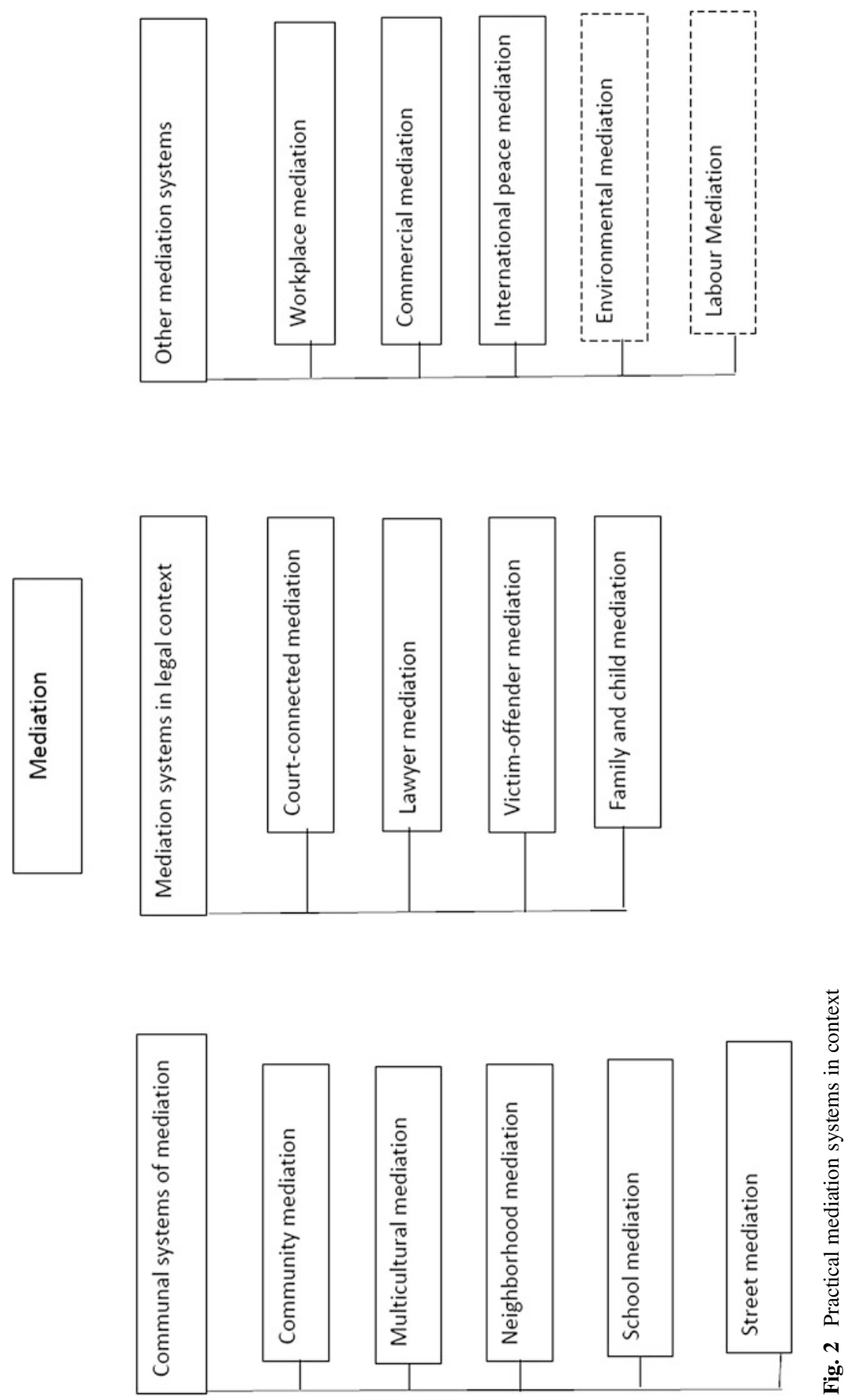
community mediation. That service uses interest-based, facilitative mediation (Nylund 2014). The background of this system is also the thinking of Christie.

School mediation started in Finland in 2000. The theoretical basis of that system is a restorative approach. The objective is to resolve conflicts directly with the help of a trained pupil or teacher. In the mediation young pupils face each other, take responsibility for their actions and can contribute to creating a better atmosphere in the school. For example, cases of bullying and name-calling have been handled in mediation (Gellin 2018). In Finland, there are over 10,000 mediated cases each year. Developers of communal mediation and school mediation have had background in victim offender mediation. In Norway, there is also a comprehensive school mediation programme. The first project of school mediation was in Norway in the mid-1990s. Behind the Norwegian system is the thinking of Christie and the Restorative Justice model (Vestre 2005; Norman and Öhman 2011).

There has been also some school mediation projects in Sweden. In this time, over 100 schools are using mediation as a tool in conflict situations (Norman and Öhman 2011). In Sweden, Marklund (2007) has conducted a case study research of school mediation. The theoretical background was also restorative justice and the thinking of Christie.

In Norway, Finland and Denmark there are also street mediation systems. The idea is to stop a young person when she or he does wrong or behaves in a disorderly manner. The goal is to encourage young people to understand their own blunders, take responsibility for them and correct them. In street mediation, meeting the young person meets the complainant in a safe environment in the presence of his or her parents and the mediators.

\subsection{Mediation in Legal Context}

In Nordic countries, there is also mediation systems in legal context. All mediation systems in Western countries are acting somehow "in the shadow of the law", even community mediation systems (Merry 1982). In this context, mediation system can be categorised to the legal context if there is regulating of mediation or lawyers are involved in mediation.

\subsubsection{Victim Offender Mediation}

In Finland, Norway, Denmark and Sweden the best known mediation system is victim offender mediation. The first victim offender mediation experiment started in Finland in 1983. The Act on Mediation in criminal and certain civil cases came into force in Finland in 2006. The focus of the mediation has been on juvenile crime, and most cases have concerned assaults, criminal damages and thefts. In about one-half of the cases, the offender is under the age of 21 years. The mediators are volunteers who receive a brief training before they start working. Victim offender mediation is 
always voluntary and there is not mandatory mediation. Most of the cases comes to mediation from police and prosecutors. In Finland, there is about 12,000 cases in victim offender mediation per year. That is quite high, because criminal proceedings total about 60,000 cases per year in district courts (Grönfors 1989; Iivari 2010; Lappi-Seppälä 2015).

In Norway, the first victim offender mediation project started in 1981.The Act on Mediation came into force in 1991. The great majority of offenders in mediation are young people. In Norway, there are about 9000 cases in victim offender mediation per year. ${ }^{9}$ (Lundgaard 2015). ${ }^{10}$

In Denmark, the first experiments of victim offender mediation started in the mid-1990s. The Act on Mediation came into force in 2010. In Denmark, mediation is an option for parties in all criminal cases that are found suitable for mediation. In 2016, there was 560 cases in victim offender mediation. ${ }^{11}$ In Denmark, VOM can supplement criminal procedure but not replace it (Stoorgaard 2015). In Finland, on the other hand, mediation can in many situations replace criminal procedure in practice. Criminal law in Finland gives a possibility for prosecutors to waive charges, for courts to waive punishment and mitigate sentencing if the parties have reached settlement or agreement in case (Lappi-Seppälä 2015).

In Sweden, the first victim offender mediation experiment started in 1987. The Act of Mediation came into force 2002. In 2008, it became mandatory to offer mediation to young offenders under the age of 21 years. There is still some problems in the Swedish system. According to Marklund (2015) "[t]here is quite widespread frustration in the mediation services over the state of affairs that is exacerbated further when one sees how well it can work in both Norway and Finland." 12 (Marklund 2015).

The builders of VOM in the beginning were sociologists. The building of VOM was part of a movement that criticised the criminal justice system and was seeking alternatives to retributive system. In Nordic countries, the sentencing systems place high value in consistency and uniformity in sentencing. There is not, for example, "problem solving courts" in Nordic countries. ${ }^{13}$ The ideological background in Finland has been "humane neoclassicism". This stressed legal safeguards and repressive measures. Individualised sentencing was de-emphasised (Hinkkanen and Lappi-Seppälä 2011). In VOM the idea is to seek more individualised solutions

\footnotetext{
${ }^{9}$ About one-half of the cases in Norway are civil cases. Mediation service in Norway, like also Mediation offices in Finland, can handle also civil cases. Most of them are compensation of crime and only a few cases in both countries do not have any connection to crime.

${ }^{10}$ For more information on Norwegian victim offender mediation, see Ervasti and Nylund (2014) and Lappi-Seppälä and Tonry (2011).

${ }^{11} \mathrm{http}: / /$ konfliktraad.dk/konfliktraad-i-tal.aspx.

${ }^{12}$ See also Jacobsson et al. (2012).

${ }^{13}$ A "problem solving court movement" developed in the United States in the 1980s, and there are, for example, drug courts, community courts, domestic violence courts and mental health courts. Today, there is problem solving courts also in Canada, Ireland and Scotland. See e.g. Lane (2003) and Boldt (2014).
} 
to problems or misbehaving of the people. In the background of developing VOM was the thinking of Christie. Researchers were also inspired by the reflexive law of Günther Teubner, at least in Finland and Denmark.

\subsubsection{Judicial Settlement Efforts and Court-Connected Mediation}

Judicial settlement efforts in civil procedure plays an important role in all Nordic countries (Ervasti 2014; Ervo and Nylund 2016). For example, according to Finnish legislation, a judge is required to investigate the prospects for settling a civil case during its preparation and pursue an amicable resolution of the matter. A judge may also make a proposal for a settlement. The promotion of settlement in civil proceedings is not a matter of mediation as such, but a matter of promoting an amicable resolution in judicial proceedings. Many provisions on judicial proceedings restrict the actions of the judge in promoting a settlement. The objective is also that the reached settlement complies with the substantive law.

In Finland, the number of settlements certified by the district courts has risen nearly to 2500 per year. Moreover, not all of parties who reach settlements request they be certified. Many judges surmise that almost one-half of the cases that they deal with end in one or another sort of settlement. According to empirical studies, some judges are promoting settlement very strongly and some others are quite passive in that area (Ervasti 2004; Adrian 2016).

Theoretically settlement promotion can describe some kind of compromising or conciliation system or "settlement driven mediation". It is not really mediation. A judge most follow the rules of fair trial in civil process and she or he cannot be mediator and use mediation techniques, such as private meetings, in that process. In the word of Nylund: "Judicial settlement activities should not be called mediation in English. The process is strictly settlement focused; the judge is, in my opinion, correctly prohibited from using mediation techniques and, therefore, the ability to generate 'better' outcomes." (Nylund 2014).

In Denmark, there is a specific system in civil cases where a judge tells after a main hearing what kind of judgement he or she probably will give and the parties will make a settlement grounding to that approximation. Over $90 \%$ of all cases will be settled in that way. There is not any regulation of such activities. Judges has developed that system in their everyday work (von Eyben 1987).

One problem with discourse in Nordic countries is that in Danish and in Norwegian has been used term "mediation" (mekling/mekling) also of judicial settlement efforts or promoting settlement in civil procedure.

Finland, Norway and Denmark has introduced a court connected mediation system. In Norway, there started an experiment of court connected mediation in 1997. It has been a permanent system from 2008 (Bernt 2011; Nylund 2010) after an evaluation of the experiment (Knoff 2001). Denmark started an experiment in 2003 
and a system has been permanent from 2008 (Adrian 2012) after evaluation of the experiment (Roepstoff and Kyvsgaard 2005).

In Finland, there was not any experiments. In the beginning of 2006, the Act on court-connected mediation entered into force. Court-connected mediation is a procedure, voluntary to the parties and managed by a judge, aiming at a situation where parties themselves can find a satisfactory resolution to their conflict.

The court decides whether mediation is to be undertaken. The court proceedings are interrupted for the duration of the mediation. When a judge decides to refer parties to mediation, another judge of same district court act as a mediator.

The theoretical basis of Nordic court-connected mediation is a facilitative mediation model. In Finland, nobody else other than a judge can act as a mediator in court connected mediation. In Denmark, court-connected mediators are judges and lawyer. In Norway, primarily judges act as mediators but others are allowed, too. In this time there are about 2000 cases in court connected mediation per year in Finland. It is quite a lot, because there are about 8000 disputed civil cases in district courts per year (Ervasti 2014, Salminen and Ervasti 2015). In Denmark, 1146 cases were referred to mediation in $2016,{ }^{14}$ which amounts to about $2 \%$ of eligible cases. There is large variation in the number of settled cases in court-connected mediation in Nordic countries (Adrian 2016). Norway has seen been over 400 cases referred to mediation per year (Lundström 2013).

In Sweden, there is not the same kind of court-connected mediation system than in Finland, Norway and Denmark. There is possible also in Sweden to use "special mediator" in civil process, but it has been used very rare (Dahlqvist 2014). It has been said that the main reason why there is not court-connected mediation system in Sweden is simply the significant role of judicial settlement efforts in that country (Lindell 2004; Ficks 2008).

A Nordic court connected mediation model where judges are acting as mediators is quite unique. In many countries, there is a referral-system where courts can send a case to out-off-court mediation. In Norway and Finland some judges, advocates and researchers was inspired by mediation and started to lobby system to law makers and politicians. Some judges had also unofficial experiments in the court system. For example, in Finland, law makers and state officers were not very enthusiastic to build a new system, but the Minister of Justice was interested in the proposal of judges. So, the system has come to Nordic countries from the down to up. In background there was also efforts to limit the amount of court cases and the costs of court system (see e.g. Reform af den civile retspleje V 2006).

\footnotetext{
${ }^{14} \mathrm{http}: / /$ www.domstol.dk/om/talogfakta/statistik/Documents/Civile\%20sager/2016/Byretter_ civile_sager_retsmaegling_2016.pdf.
} 


\subsubsection{Lawyer Mediation}

There is also lawyer mediation in Nordic countries. In order to resolve different kind of conflicts the Finnish Bar Association founded its own mediation system in 1998. At the same time, its mediation rules were approved. The system is based on voluntariness. The parties to the conflict appoint an advocate to act as a mediator between them. In mediation by lawyers facilitative approach has been adopted. The Norwegian Bar Association founded mediation system in the year 2000. (Austbø and Engerbretsen 2003). In the year 2003 Danish Bar and Law Society established an Association of Danish Mediation Advocates (Vindel $\varnothing v$ 2013). At least in Finland but also in other Nordic countries the whole culture of lawyers like also court culture is changing to direct of "negotiated law".

\subsubsection{Family Mediation}

There is also family mediation in all Nordic countries. For example, in Finland, regulation on mediation in divorce matters has existed for over 60 years. Family mediators can provide help and support in the event of family disputes and conflicts that concern compliance with decisions and agreements on child custody and right of access. The primary aim of mediation is to protect the best interests of children. Family mediation is mainly the responsibility of municipal social welfare authorities who typically have a university-level education. They help the parties to divorce cases agree on the custody of the children and the right of access (Haavisto 2018). Sweden has quite the same system (Norman and Öhman 2011). Family cases can be mediated also in court-connected mediation (Salminen 2018) but also during the court process in Norway (Bernt 2018). ${ }^{15}$

The roots of family mediation in Nordic countries rests originally in Christian values. The main effort earlier was to keep the family together and prevent divorce. Even in this time there is obligatory family mediation in Norway in divorce situations. In this time it has been stressed more the welfare of the child or best interests of the child. In theoretical discussion in Nordic countries, the best interests of the child is one of the main questions in the field of family mediation.

\subsection{Other Mediation Systems}

There are also many other mediation systems in Nordic countries. Workplace mediation is a new phenomenon. In workplace mediation, a company employs a mediator to assist in resolving conflicts within the work community. Conflicts can, for instance, relate to bullying. Conflict in a work community can in many ways be

\footnotetext{
${ }^{15}$ For family mediation in Sweden, see Rystedt (2012).
} 
counter-productive for the operation and performance of the work community. In Finland, there are about 100 to 200 cases per year in that system. In Finland, workplace mediation has developed primarily on the basis of the victim offender mediation and restorative justice model.

There is also commercial mediation or business mediation in Nordic Countries. ${ }^{16}$ For example, the Finland Arbitration Institute of the Finland Chamber of Commerce has had its own mediation system from 2016 akin to the Arbitration Institute of the Stockholm Chamber of Commerce, the Arbitration Institute of Oslo Chamber of Commerce and the two arbitration institutes in Denmark. The theoretical basis of the mediation of the Finnish Arbitration Institute is a facilitative mediation model.

Mediation by the Finnish Association of Civil Engineers deals mostly with disputes concerning building projects. The building trade is an industry prone to conflicts as the projects often involve a network of multiple actors. Experts in the industry as well as lawyers can act as mediators. In connection with the mediation, it is also possible to choose a procedure that is based on an arbitration agreement and concludes when a settlement is reached.

International peace mediation, on the other hand, is a widely used procedure. Mediation cases have increased radically since the mid-1990s. Norway has been a pioneer in international mediation in the early 1990s. Also, Finland and Sweden have been very active in this area. There have been several internationally acknowledged peace mediators in Nordic countries, such as Finnish Martti Ahtisaari, who has awarded the Nobel Prize. International peace mediation focuses on international crisis management and prevention of violence. Peace and conflict research is also very dynamic in Nordic countries (see e.g. Lehti 2014).

In recent years, a possibility for environmental mediation has also been discussed. In 2009, there was also an experiment of environmental mediation in Finland. Mediation has not been taken into account in planning or in the permit procedure concerning changes in land use, although it could be used as a conflict-solving method. When it comes to administrative matters, there is no organised mediation in Finland.

In Nordic countries in labour mediation can be handled conflicts between trade unions and employer's organisations. At least in Finland it is a mixed conflict resolution system and not a "pure" mediation system.

\section{Mediation in Action}

Mediation in action is based always on some theory and some practical system of mediation. The underlying theory is direct mediation on a practical level. Different theories of mediation requires different mediation style and techniques. In literature has been discussed plenty of different kind of styles and techniques in mediation

\footnotetext{
${ }^{16}$ For commercial mediation in Europe, see Richbell (2014).
} 
(see e.g. Alfini 1991-1992; Oberman 2008; Charkoudian et al. 2009; Marcum et al. 2012; Kressel et al. 2012; Baitar et al. 2013; Ervasti and Nylund 2014). According to Menkel-Meadow (1984), the orientation in negotiation leads to a mindset about what can be achieved, which, in turn, affects the behaviour chosen, which, in turn, affects the solution arrived at.

Typically techniques in mediation are, for example, active listening, questioning, caucuses (separate meetings), reality testing and brainstorming. Using a variety of techniques constitutes a wholeness, which one can call a "mediation style". Different mediation theories requires different mediation styles. Figure 3 shows what kind of techniques are typical in different models of mediation and conciliation.

For the evaluative mediation style, it is typical to evaluate the case, provide information, make proposals for settlement-like also reality testing - and to use caucuses. For the compromising style, it is typically shuttle mediation where the parties are in different rooms and a mediator delivers offers and counter-offers between the parties. That kind of activity can be called strategic bargaining. For the facilitative style, typical use includes such techniques as active listening, questioning and brainstorming. For the transformative style, typical use includes empowering, recognition and supporting self-determination of the parties. In transformative mediation, the parties are controlling the process and results. In facilitative mediation, the mediator is the leader of the process and the parties have responsibility of the results. In evaluative mediation, the mediator has a responsibility of the process but also at least in part of the results.

The problem is that mediators in their everyday work are many times acting in a different way that they think themselves or what theory of mediation postulates. For example, mediation in victim offender mediation is not always following the theory of the restorative justice model and court connected mediation is not always

\begin{tabular}{|l|l|l|l|}
\hline Evaluative & Compromising & Facilitative & Transformative \\
\hline Evaluation & $\begin{array}{l}\text { Forwarding offers } \\
\text { and counter offers }\end{array}$ & $\begin{array}{l}\text { Improving } \\
\text { communication }\end{array}$ & Empowering \\
\hline $\begin{array}{l}\text { Provision of } \\
\text { information }\end{array}$ & "Shuttle mediation" & Active listening & Recognition \\
\hline $\begin{array}{l}\text { Proposals for } \\
\text { settlement }\end{array}$ & $\begin{array}{l}\text { Promoting middle } \\
\text { range solutions }\end{array}$ & Replacement of terms & $\begin{array}{l}\text { Supporting self- } \\
\text { determination and } \\
\text { self-confidence }\end{array}$ \\
\hline Reality testing & $\begin{array}{l}\text { Highlighting the } \\
\text { benefits of quick } \\
\text { solution }\end{array}$ & $\begin{array}{l}\text { Questioning } \\
\text { activate their inherent } \\
\text { capacity for } \\
\text { deliberation and } \\
\text { decision making }\end{array}$ \\
\hline Caucuses & $\begin{array}{l}\text { Highlighting } \\
\text { weakness of other } \\
\text { processes and } \\
\text { solutions }\end{array}$ & $\begin{array}{l}\text { Brainstorming/ } \\
\text { development of } \\
\text { alternatives }\end{array}$ & $\begin{array}{l}\text { Enhancing } \\
\text { interpersonal } \\
\text { communication }\end{array}$ \\
\hline
\end{tabular}

Fig. 3 Typical techniques in different mediation models 
following facilitative model. Especially legal context mediation systems evolve often mixed systems. In practice, it means that used mediation styles and mediation techniques will diverge from what theory requires. In that case, the quality of the mediation process or outcome is not necessarily so good than it could or should be. This kind of action has been called "stylistically flexible", "eclectic style", "situational style" and "hybrid" or "mixed" conflict resolution system (Imperati et al. 2007; Kressel et al. 2012; Marcum et al. 2012; Ervasti and Nylund 2014; Ervasti and Salminen 2017). In mixed or hybrid conflict resolution systems ethical principles of mediation are, in fact, always not realised and, on the other hand, people do not get even a formal legal protection-instead, it can be a semi-legal system or semi-mediation (Ervasti and Nylund 2014).

Legislation in Nordic countries concerning mediation (court-connected, VOM, family) gives a frame for mediation but there is not detailed regulation or orders on how the mediation process should be. So, mediators have many possibilities to choose a mode of action.

In many studies in Nordic countries has founded gap between the theoretical basis of a mediation system and the behaviour of mediators. Here are examples from Finland, Denmark, Sweden and Norway.

In Finland, Elonheimo (2004) has conducted research on the victim offender mediation in Finland. In that study it has been observed 16 mediation cases in a mediation office of the Turku district (nine assaults and seven property crimes). The research found a gap between the restorative mediation model and actual behaviour of mediators. There was a lack of dialogue and lack of producing "re-integrative shame."17

Adrian (2012) has conducted research of court-connected mediation in Denmark. She has used observations $(n=20)$, interviews of mediators $(n=20)$ and the parties $(\mathrm{n}=35)$ and documents $(\mathrm{n}=42)$ as research material. According to Adrian, in many cases interests and needs was not on focus in mediation like the theoretical basis of mediation demands. In some cases, the mediator had an evaluative mediation style and mediators were not always neutral. Some of mediators and also parties have had difficulties in court-connected mediation to get free of the roles they have usually in litigation.

Jacobsson et al. (2012) have conducted research of victim offender mediation in Sweden. They have analysed 25 mediation meetings, which were recorded and transcribed. According to researchers, the Swedish mediation policy in practice seems "not to be fully congruent with restorative justice ideology". Mediation also seems to be quite offender-focused. There is also "risk that victims in some cases can feel that they are forces to act in line with the offender's will, with or not, personal benefit".

Mykland (2011) has conducted research of court-connected mediation in Norway. She has observed 15 mediation cases. The basis of Norwegian court-connected mediation is facilitative interest based mediation. According to Mykland, many mediators have used power and had an evaluative style. Sometimes they have

\footnotetext{
${ }^{17}$ Takala (1988) and Mielityinen (1989) has the same results in their studies.
} 
combined mediation and arbitration together. There is also lot of variation in the behaviour and styles of mediators. So, there is a gap between mediator style and the theoretical basis of mediation.

There can be many reasons why the mediator behaves differently than the underlying theory postulates. Maybe the mediator does not know what he or she really are doing or does not care of theory or does not consider theory as important. It is very important to take care of education of mediators so that they can recognise what they are doing and to reflect on it. It is also very important to conduct empirical studies and research on mediation in order to develop the system.

Vibeke Vindeløv (2013), has stressed that "mediator must take on the role of the reflective practitioner" who "trusts the parties to bring their knowledge and skills to bear on the problem". She emphasises that the parties must define how broad the mediation should be. This flexibility does not mean that "anything goes". ${ }^{18}$

\section{Conclusions}

As a whole there are many kinds of conflict resolution systems and mediation systems in a complex and multidimensional postmodern society. In Nordic countries, especially in the 2000 s, mediation systems have increased rapidly. At the same time, the research community in this area has become quite dynamic. There is increasingly more research in the field of conflict resolution and mediation in Nordic countries and lot of co-operation amongst researchers in these countries. Nonetheless, there is still a lack of empirical studies and evaluations of the systems and, at least in Finland, there is also a lack of sufficient training in many areas of mediation. ${ }^{19}$ It is, for example, very difficult to find usable and comparable information of the rates of mediation cases in different mediation systems. Both empirical and theoretical studies are needed. Also needed is the development of mediation training.

\section{References}

Adrian L (2012) Mellem retssag og rundbordssamtale: Retsmægling i teori og praksis. Jurist- og $\varnothing$ konomforbundets Forlag, København

Adrian L (2016) The role of court-connected mediation and judicial settlement efforts in the preparatory stage. In: Ervo L, Nylund A (eds) Current trends in preparatory proceedings. A comparative study of Nordic and former communist countries. Springer, Cham, pp 209-231

Adrian L, Mykland S (2014) Creativity in court-connected mediation: myth or reality? Negot J 30:421-439

\footnotetext{
${ }^{18}$ Vindeløv (2013).

${ }^{19}$ The University of Copenhagen has a master's degree programme in mediation. http://jura.ku.dk/ uddannelser/efterogvidereuddannelse/master.
} 
Albrecht B (2010) Multicultural challenges for restorative justice: mediators' experiences from Norway and Finland. J Scand Stud Crim Crime Prev 11:3-24

Alfini J (1991) Trashing, bashing, and hashing it out: is this the end of 'good mediation'? Fla State Univ Law Rev 19:47-75

Alfini J, Press S, Sternlight J, Stulberg J (2001) Mediation theory and practice. LexisNexis, Newark Asmussen IH (2018) Modern view of identity change - what is going on in mediation. In: Nylund A, Ervasti K, Adrian L (eds) Nordic mediation research. Springer, Cham, pp 133-143

Austb $\varnothing$ A, Engebretsen G (2003) Mekling i rettskonflikter. Retsmekling, mekling ved advokater og mekling i forliksrådene og konfliktrådene. Cappalen Akademisk Forlag, Oslo

Aubert V (1963) Competition and dissensus: two types of conflict and conflict resolution. J Confl Resolut 7:26-42

Aubert V (1967) Courts and conflict resolution. J Confl Resolut 11:40-51

Bernt C (2011) Meklerrollen ved mekling i domstolene. Fagbokförlaget, Bergen

Bernt C (2018) Custody mediation in Norwegian courts: a conglomeration of roles and processes. In: Nylund A, Ervasti K, Adrian L (eds) Nordic mediation research. Springer, Cham, pp 105-133

Boldt R (2014) Problem-solving courts and pragmatism. Maryland Law Rev 73:1120-1172

Braithwaite J (1996) Restorative justice and a better future. Dalhousie Rev 76:9-31

Bush R, Folger J (2005) The promise of mediation. New and Revised edn. Jossey-Bass, San Francisco

Christie N (1977) Conflicts as property. Br J Criminol 17:1-15

Charkoudian L, de Ritis C, Buck R, Wilson C (2009) Mediation by any other name would smell as sweet - or would it? Confl Resolut Q 26:293-316

Dahlqvist A (2014) Mediation in Swedish courts: change by EU directive? In: Ervo L, Nylund A (eds) In the future of civil litigation. Access to court and court-annexed mediation in the Nordic countries. Springer, Cham, pp 137-156

Dragos D, Neamtu B (eds) (2014) Alternative dispute resolution in European administrative law. Springer, Heidelberg

Eckhoff T (1966) The mediator, the judge and the administrator in conflict resolution. Acta Sociol 10:148-172

Elonheimo H (2004) Restoratiivinen oikeus ja suomalainen sovittelu. Oikeus 33:279-299

Ervasti K (2004) Käräjäoikeuksien sovintomenettely. Empiirinen tutkimus sovinnon edistämisestä riitaprosessissa. Oikeuspoliittinen tutkimuslaitos, Helsinki

Ervasti K (2014) Court-connected mediation in Finland: experiences and visions. In: Ervo L, Nylund A (eds) In the future of civil litigation. Access to court and court-annexed mediation in the Nordic countries. Springer, Cham, pp 121-135

Ervasti K, Nylund A (2014) Konfliktinratkaisu ja sovittelu. Helsinki, Edita

Ervasti K, Salminen K (2017) Conflict resolution in the garden of forking paths. In: Rønne A, Adrian L, Nielsen L (eds) Fred, forsoning og mægling. Festskrift til Vibeke Vindeløv. Jurist og $\varnothing$ konomforbundets forlag, København, pp 95-110

Ervo L, Nylund A (eds) (2014) The future of civil litigation - access to courts and court - annexed mediation in the Nordic countries. Springer, Cham

Ervo L, Nylund A (eds) (2016) Current trends in preparatory proceedings. A comparative study of Nordic and former communist countries. Springer, Cham

Ficks E (2008) Models of general court-connected conciliation and mediation for commercial disputes in Sweden, Australia and Japan. J Jpn Law 25:131-152

Folberg J, Milne A (1988) Divorce mediation. Theory and practice. Guiford Press, New York

Galanter M (1986) The emergence of the judge as a mediator in civil cases. Judicature 69:257-262

Galtung J (2000) Conflict transformation by peaceful means (the transcend method). United Nations disaster management training programme. http://www.transcedn.org/pctrcluj2004/ TRANSCEND_manual.pdf

Gellin M (2018) Restorative approach and mediatoin in Finnish schools: from conflicts to restoration. In: Nylund A, Ervasti K, Adrian L (eds) Nordic mediation research. Springer, Cham, pp 247-266 
Goldberg S, Sander F, Rogers N (1999) Dispute resolution. Negotiation, mediation and other processes, 3rd edn. Aspen Law \& Business, New York

Grönfors M (1989) Mediation - experiment in Finland. In: Albrecht PE, Bakes O (eds) Crime prevention and intervention. Walter de Gruyter, Berlin - New York

Haavisto V (2018) Developing family mediation in Finland: the change process and the practical outcomes. In: Nylund A, Ervasti K, Adrian L (eds) Nordic mediation research. Springer, Cham, pp 41-66

Hammerslev O (2010) Convergence and conflict perspectives in Scandinavian studies of the legal profession. Int J Leg Prof 17:135-152

Hammerslev O, Madsen MR (2014) The return of sociology in Danish socio-legal studies: a survey recent trends. Int J Law Context 10:397-415

Hinkkanen V, Lappi-Seppälä T (2011) Sentencing theory, policy, and research in the Nordic countries. In: Tonry M, Lappi-Seppälä T (eds) Crime and justice in Scandinavia, vol 40. Crime and Justice, Chicago, pp 349-404

Iivari J (2010) Providing mediation as a Nationwide Service. Empirical research on restorative justice in Finland. In: Vanfraechem I, Aertsen I, Willemsens J (eds) Restorative justice realities. Empirical research in a European context. Eleven, The Hague, pp 95-119

Imperati S, Brownmiller D, Marshall D (2007) If Freud, Jung, Rogers, and Beck were mediators, who would the parties pick and what are the Mediator's obligations? Idaho Law Rev 43:643-708

Jacobsson M, Wahlin L, Andersson T (2012) Victim-offender mediation in Sweden: is the victim better off? Int Rev Victimol 18:229-259

Knoff RH (2001) Baskere? Billigare? Vennligere? Evaluering av prøveordningen med rettsmekling. Rapport for justisdepartementet

Kressel K, Henderson T, Reich W, Cohen C (2012) Multidimensional analysis of conflict mediator style. Confl Resol Q 30:135-171

Lane E (2003) Due process and problem-solving courts. Fordham Urban Law J 30:955-1026

Lappi-Seppälä T, Tonry M (2011) Crime, criminal justice and criminology in Nordic countries. In: Tonry M, Lappi-Seppälä T (eds) Crime and justice in Scandinavia. Crime and justice, vol 40. The University of Chicago Press, Chicago, pp 1-32

Lappi-Seppälä T (2015) Finland. In: Dünkel F, Grzywa-Holten J, Horsfield P (eds) Restorative justice and mediation in penal matters. A stock-taking of legal issues, implementation strategies and outcomes in 36 European countries, vol 1. Forum Verlag Godersberg, Mönchengladbach, pp 243-266

Lehti M (ed) (2014) Nordic approaches to peace mediation. Research, practices and policies. Tapri Studies in Peace and Conflict Research No 101, Tampere

Letto-Vanamo P, Tamm D (2017) Adjudication or negotiation. Mediation as a non-modern element in conflict resolution. In: Rønne A, Adrian L, Nielsen L (eds) Fred, forsoning og mægling. Festskrift til Vibeke Vindeløv. Jurist og økonomforbundets forlag, København, pp 213-225

Lindel B (2004) Mediation in Sweden. ADR Bull 7(5):1-8

Lundgaard JM (2015) Norway. In: Dünkel F, Grzywa-Holten J, Horsfield P (eds) Restorative justice and mediation in penal matters. A stock-taking of legal issues, implementation strategies and outcomes in 36 European countries, vol 2. Forum Verlag Godersberg, Mönchengladbach, pp 619-636

Lundström B (2013) Mediationens gennembrud. Advokaten 13(3):37-39

Marcum T, Stoner C, Perry S (2012) Reframing the mediation lens: the call for a situational style of mediation. South Illinois Univ Law Rev 36:317-334

Marklund L (2007) Skolmedling i teori och praktik. Licentiate's Dissertation, Uppsala Universitet, Uppsala

Marklund L (2015) Sweden. In: Dünkel F, Grzywa-Holten J, Horsfield P (eds) Restorative justice and mediation in penal matters. A stock-taking of legal issues, implementation strategies and outcomes in 36 European countries, vol 2. Forum Verlag Godersberg, Mönchengladbach, pp 917-933 
Mathiesen T (1979) Ideologi og motstand. Elementer til en politisk strategi. Pax forlag, Oslo McCorkle S, Reese M (2005) Mediation theory and practice. Pearson Education Inc., Boston Menkel-Meadow C (1984) Toward another view of legal negotiation: the structure of problem solving. UCLA Law Rev 31:754-842

Menkel-Meadow C (1996) The trouble with the adversary system in a postmodern, multicultural world. William Mary Law Rev 38:5-44

Menkel-Meadow C (2016) Mediation and its applications for good decision making and dispute resolution. Honorary doctorate in human sciences KU Leuwen 9 February 2016. Acta Falconis. Intersentia, Cambridge

Merry S (1982) The social organization of mediation in nonindustrial Societys: implications for informal community justice in America. In: Abel R (ed) The politics of informal justice. Academic Press, New York

Mielityinen I (1989) Rikos ja sovittelu. Valikoituminen, merkitys ja uusintarikollisuus. OPTL, Helsinki

Mykland S (2011) En studie av mekleratferd i norske rettsmeklinger. NHH. Institutt for strategi og ledelse. Ph.D. thesis No 2011/02

Norman J, Öhman L (2011) Medling och andra former av konflikthantering. Iustus Förlag, Uppsala Nylund A (2010) Meklingsmodeller i tvisteloven: terapi, tvekamp eller kreativ problemløsning? Lov og Rett 49(5):272-284

Nylund A (2014) The many ways of civil mediation in Norway. In: Ervo L, Nylund A (eds) In the future of civil litigation. Access to court and court-annexed mediation in the Nordic countries. Springer, Cham, pp 97-119

Nylund A (2018) A dispute systems design perspective on Norwegian child custody mediation. In: Nylund A, Ervasti K, Adrian L (eds) Nordic mediation research. Springer, Cham, pp 9-29

Oberman S (2008) Style vs. Model: why quibble? Pepperdine Dispute Resolut Law J 9:1-62

Rasmussen KB (2018) When is restorative justice? In: Nylund A, Ervasti K, Adrian L (eds) Nordic mediation research. Springer, Cham, pp 145-179

Reform af den civile retspleje V (2006) Retsmægling. Betænkning nr. 1481. København

Richbell D (2014) How to master commercial mediation. Bloomsbury, London

Riskin L (1996) Understanding mediators' orientations, strategies, and techniques. Harv Negot Law Rev 1:7-51

Roepstorff J, Kyvsgaard B (2005) Forsøg med retsmægling - en evalueringsrapport. Justitsministeriets Forskningsenhed, København

Rystedt E (2012) Mediation regarding children - is the result always in the best interest of child? A view from Sweden. Int J Law Policy Family 26:220-241

Salminen K (2018) Is mediation in the best interests of a child from the child law perspective? In: Nylund A, Ervasti K, Adrian L (eds) Nordic mediation research. Springer, Cham, pp 209-222

Salminen K, Ervasti K (2015) Tuomioistuinsovittelun yleistyminen ja tuomioistuimen tehtävät. Lakimies 113(5):591-612

Stoorgaard A (2015) Denmark. In: Dünkel F, Grzywa-Holten J, Horsfield P (eds) Restorative justice and mediation in penal matters. A stock-taking of legal issues, implementation strategies and outcomes in 36 European countries, vol 1. Forum Verlag Godersberg, Mönchengladbach, pp 183-202

Takala J-P (1988) Moraalitunteet rikosten sovittelussa. OPTL, Helsinki

Umbreit M (1988) Mediation of victim offender conflict. J Dispute Resolut 85:1-21

Vestre M (2005) Konfliktløsning gjennom elevmedgling. En kvalitativ studie av tre meglingssaker. Hovedoppgave i sociologi. Universitetet i Oslo, Oslo

Vindeløv V (2007) Mediation - a non-model. Djøf Publishing, Copenhagen

Vindel $\varnothing v$ V (2012) Reflexive mediation. With a sustainable perspective. Jurist- og Økonomforbundets Førlag, København

Vindel $\varnothing v$ V (2013) Konfliktmægling. En refleksiv model. 3. reviderede udgave. Jurist- og Økonomforbundets Førlag, København 
von Eyben WE (1987) Dommertilkendegivelser. København

Winslade J, Monk G (2001) Narrative mediation. A new approach to conflict resolution. Jossey-Bass Publishers, San Francisco

Open Access This chapter is licensed under the terms of the Creative Commons Attribution 4.0 International License (http://creativecommons.org/licenses/by/4.0/), which permits use, sharing, adaptation, distribution and reproduction in any medium or format, as long as you give appropriate credit to the original author(s) and the source, provide a link to the Creative Commons license and indicate if changes were made.

The images or other third party material in this chapter are included in the chapter's Creative Commons license, unless indicated otherwise in a credit line to the material. If material is not included in the chapter's Creative Commons license and your intended use is not permitted by statutory regulation or exceeds the permitted use, you will need to obtain permission directly from the copyright holder. 